\title{
Osteoid Osteoma of the Middle Phalanx of the Third Finger in a Child Mimicking a Malignancy
}

\author{
Georgi P. Georgiev' ${ }^{1}$, Svetoslav A. Slavchev², Iva N. Dimitrova3 \\ ${ }^{1}$ Department of Orthopaedics and Traumatology, Queen Giovanna University Hospital-ISUL, Medical University of Sofia, Sofia, \\ Bulgaria \\ ${ }^{2}$ Department of Orthopaedics and Traumatology, Prof. B. Boychev University Hospital of Orthopaedics, Medical University of \\ Sofia, Sofia, Bulgaria \\ ${ }^{3}$ Department of Cardiology, St. Ekaterina University Hospital, Medical University of Sofia, Sofia, Bulgaria
}

\section{Correspondence:}

Georgi P. Georgiev, Department of Orthopaedics and Traumatolgy, Queen Giovanna University Hospital - ISUL, Medical University of Sofia, 8 Bialo more Str., 1527 Sofia, Bulgaria

E-mail: georgievgp@yahoo.com Tel: +359 884493523

Received: 28 Sept 2016

Accepted: 15 Aug 2017

Published Online: 25 Sept 2017

Published: 30 June 2018

Key words: osteoid osteoma, child, phalanx, surgery

Citation: Georgiev GP, Slavchev SA, Dimitrova IN. Osteoid osteoma of the middle phalanx of the third finger in a child mimicking a malignancy. Folia Med (Plovdiv) 2018;60(2): 314-7.

doi: 10.1515/folmed-2017-0085
Osteoid osteoma is a rare occurrence in the hand, especially in children. We report here a rare case of a 12-year-old boy complaining of growing painful swelling of the middle phalanx of the third finger that had started 3 months earlier and had not responded to anti-inflammatory medication. Based on the clinical findings and plain radiographs, osteomyelitis or Ewing's sarcoma was suspected. However, MRI revealed the typical characteristics of osteoid osteoma. The lesion was excised, and the histological examination confirmed the diagnosis. We make a brief review of the literature concerning this uncommon localization and discuss the differential diagnosis and treatment modalities.

\section{INTRODUCTION}

In 1935, Jaffe was the first to describe the osteoid osteoma (OO) as a distinct entity giving rise to a characteristic clinical picture. ${ }^{1}$ The $\mathrm{OO}$ is a well known benign bone tumor of uncertain origin. It is the third most common benign lesion and accounts for $11-12 \%$ of benign bone tumours. ${ }^{2,3}$ OO mainly occurs in adolescents and young adults and predominantly affects males. ${ }^{2}$ Typically, it is localized in the appendicular skeleton, usually in the lower extremity. Although this lesion is not uncommon, the hand is rarely affected especially in children. ${ }^{4}$ In these cases, the diagnosis can be very difficult and a malignancy should be excluded.

In this report we present a rare case of an $\mathrm{OO}$ affecting the middle phalanx of the third finger of the left hand in a child.

\section{CASE REPORT}

A 12-year-old boy was brought to our clinic by his parents with a painful swelling of the middle phalanx of the left middle finger of 3 months duration. On clinical examination, the middle phalanx was enlarged, bulky and tender on palpation with stretched overlying skin. No motor or sensory impairment of the finger was found. There was no previous history of trauma or infection. The laboratory findings were within normal ranges, including laboratory tests for inflammation. The range of motion in the proximal interphalangeal joint was slightly reduced compared to the contralateral hand.

Radiographs revealed soft tissue edema around the middle phalanx of the middle finger. An ovalshaped sclerotic mass in base of the phalanx was evident but a nidus was not seen in plain radiography 
(Figs 1a, 1b). On MRI, the typical characteristics of an $\mathrm{OO}$ - the nidus with surrounding bone sclerosis in the middle phalanx - were detected (Figs 1c, 1d).

Based on clinical and MRI findings, the diagnosis of $\mathrm{OO}$ was made. Conservative treatment with anti-inflammatory drugs was unsuccessful. Surgery was performed through an ulnar approach to the middle phalanx. The osteosclerotic area was trephined and the nidus was removed with a small
Eight months after surgery no clinical and radiological signs of recurrence were detected (Figs 1e, 1f).

\section{DISCUSSION}

In the literature, $\mathrm{OO}$ is described as a relatively frequent benign bone tumour, which accounts for about $5 \%$ of benign bone tumours. This lesion consists of osteoid and woven bone, surrounded by a
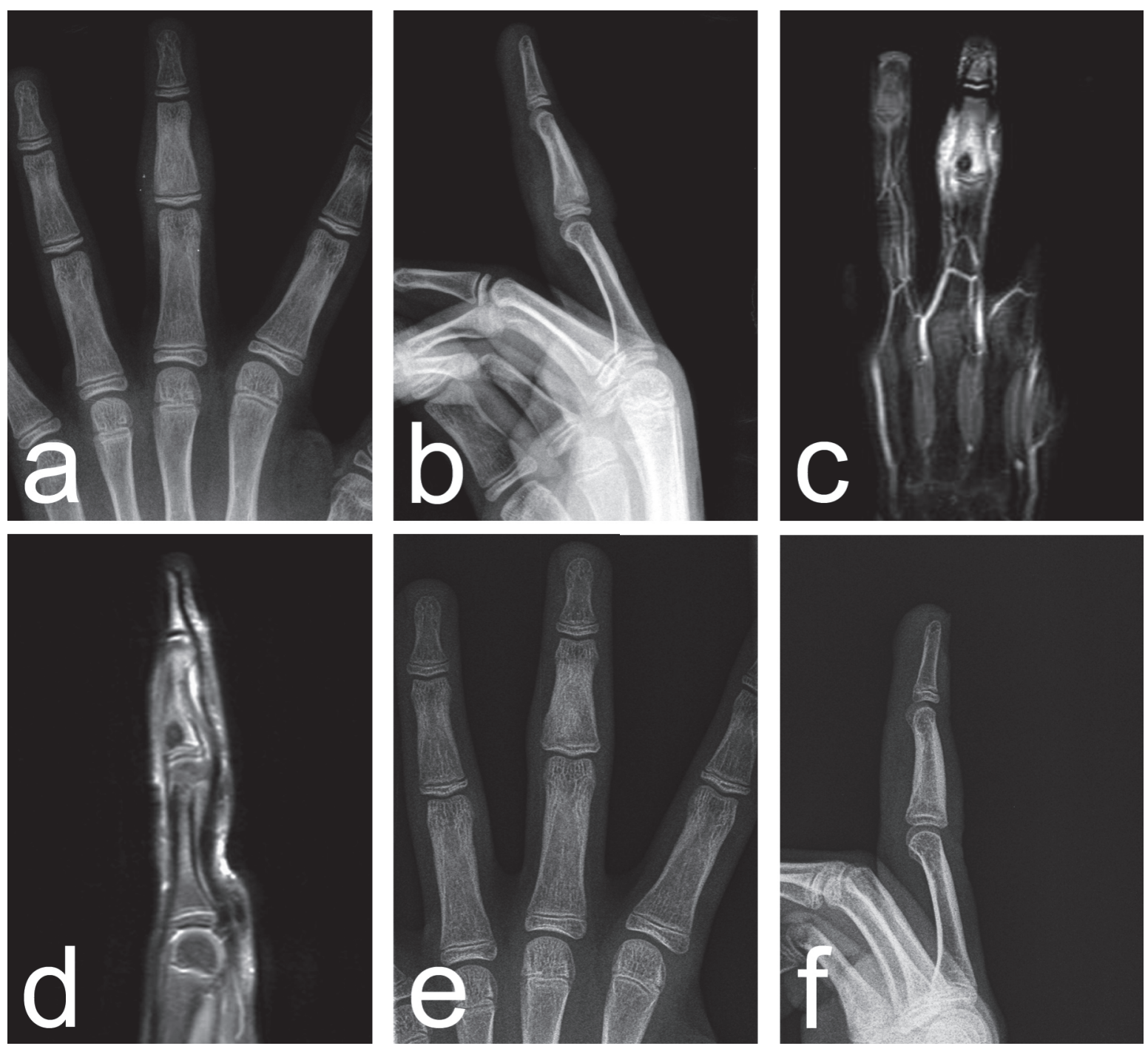

Figure 1. a, b: Preoperative radiographs; c, d: MRI scan presenting the nidus with surrounding bone sclerosis in the middle phalanx; e, f: Postoperative radiographs eight months after surgery.

curette. The wound was closed in the usual manner. In the first days following surgery, the pain was completely relieved. Immobilization of the finger was used for three weeks. Histological examination confirmed the diagnosis of $\mathrm{OO}$. halo of reactive sclerotic bone, with an average size of the nidus of less than $1.5 \mathrm{~cm}$. Usually, the $\mathrm{OO}$ is localized in the appendicular skeleton, mainly in the lower extremity. ${ }^{4}$ The localization in the hand is rare and most commonly affects the proximal phalanx. ${ }^{5}$ A double nidus of $\mathrm{OO}$ of the finger has 
also been described. ${ }^{6}$

Commonly, the OO presents with night pain in the affected region, which is relieved by antiinflammatory drugs. ${ }^{2,7}$ In the region of the hand, the OO could have atypical symptoms, as in our case. Unusual clinical signs and locations, especially at the hand, can easily result in misdiagnosis or delay in the diagnosis. ${ }^{8}$ When the diagnostic approach is challenging, the performance of different imaging modalities are essential.

The imaging studies could help for diagnosis. On radiography, the nidus is commonly presented as a radiodense central core, surrounded by a regular halo of bone sclerosis. In some cases the OO could simulate osteomyelitis, Brodie's abscess, tuberculosis, tenosynovitis and benign or malignant tumour. ${ }^{7,8}$ In our case the radiographic findings were suspicious for osteomyelitis or Ewing sarcoma. After performance of MRI with typical characteristics of OO, revealing the nidus and surrounding bone sclerosis, the diagnosis of $\mathrm{OO}$ of the middle finger was established. A CT and isotope bone scan could also be used in diagnosis as imaging modalities. ${ }^{2,3}$

After extensive review of the PubMed database we identified three similar cases published in the literature. Aghoutane and Fezzazi (2012) presented a case of a 13-year-old girl with $\mathrm{OO}$ of the first phalanx of the right middle finger. ${ }^{4}$ De Smet et al. (1998) presented a case of an 8-year-old child presenting with painless $\mathrm{OO}$ of the middle phalanx of the ring finger. ${ }^{9}$ Levy et al. (1979) described an $\mathrm{OO}$ of the distal phalanx of the thumb in a 14-year-old girl. ${ }^{10}$

OO may resolve spontaneously or after treatment with acetylsalicylic acid or nonsteroidal anti-inflammatory drugs. However, in children long term therapy is not acceptable due to gastrointestinal complications. ${ }^{3}$ In cases of unsuccessful nonoperative treatment, complete surgical excision or radiofrequency ablation could be performed. ${ }^{8}$ Surgical excision is preferable when hands or feet are affected due to the close relation of neurovascular bundles in these regions. ${ }^{8}$

In conclusion, in cases like ours, accurate diagnosis could be made only with a high degree of suspicion and carefully selected imaging modalities.

\section{REFERENCES}

1. Jaffe HL. Osteoid-osteoma. A benign osteoblastic tumor composed of osteoid and atypical bone. Arch Surg 1935;31(5):709-28.

2. Kitsoulis P, Mantellos G, Vlychou M. Osteoid osteoma. Acta Orthop Belg 2006;72(2):119-25.

3. Ozbek O, Nayman A, Koç O, et al. Radiofrequency ablation of phalangeal osteoid osteoma: technical challenges encountered in small bones. Jt Dis Relat Surg 2011;22(2):107-9.

4. Aghoutane EM, El Fezzazi R. Osteoid osteoma of the phalanx in children and diagnostic problems: report of one case. Chir Main 2012;31(4):199-201.

5. Ramos L, Santos JA, Santos G, et al. Radiofrequency ablation in osteoid osteoma of the finger. J Hand Surg 2005;30(4):798-802.

6. Allieu Y, Lussiez B, Benichou M, et al. A double nidus osteoid osteoma in a finger. J Hand Surg 1989;14(3):538-41.

7. Turkmen I, Alpan B, Soylemez S, et al. Osteoid osteoma of the great toe mimicking osteomyelitis: a case report and review of the literature. Case Rep Orthop 2013;2013:234048.

8. Nasab SAM, Pipelzadeh M. Osteoid osteoma of proximal phalanx of the index finger of the right hand. Open J Med Imaging 2011;1(2):50-2.

9. De Smet L, Spaepen D, Zachee B, et al. Painless osteoid osteoma of the finger in a child. Case report. Chir Main 1998;17(2):143-6.

10. Levy Y, Rosenheck S, Greiff M, et al. Osteoid osteoma of the distal phalanx of the thumb. Acta Orthop Scand 1979;50(6 Pt 1):667-9. 


\title{
Остеоидная остеома средней фаланги третьего пальца ребёнка, имитирующая злокачественность
}

\author{
Георги П. Георгиев ${ }^{1}$, Светослав А. Славчев ${ }^{2}$, Ива Н. Димитрова ${ }^{3}$ \\ ${ }^{1}$ Кафедра ортопедии и травматологии, УМБАЛ „Кралица Йоанна“- ИСУЛ, Медицинский университет- София, София, \\ Болгария \\ 2 УМБАЛ ортопедии „Проф. Б. Бойчев“, Медицинский университет - София, София, Болгария \\ ${ }^{3}$ Кафедра кардиологии, УМБАЛ „Св. Екатерина“, Медицинский университет - София, София, Болгария
}

Адрес для корреспонденции:

Георги П. Георгиев, Кафедра ортопедии и травматологии, УМБАЛ „Кралица Йоанна“- ИСУЛ, Медицинский университет - София, ул. „Бяло Море“ № 8, 1527, София, Болгария

E-mail: georgievgp@yahoo.com Tel: +359884493523

Дата получения: 28 сентября 2016

Дата приемки: 15 августа 2017 Дата онлайн публикации: 25 сентября 2017

Дата публикации: 30 июня 2018

Ключевые слова: остеоидная остеома, ребёнок, фаланга, хирургия

\section{Образец цитирования:}

Georgiev GP, Slavchev SA, Dimitrova IN. Osteoid osteoma of the middle phalanx of the third finger in a child mimicking a malignancy. Folia Med (Plovdiv) 2018;60(2): 314-7.

doi: 10.1515/folmed-2017-0085
Остеоидная остеома является редким проявлением в руке, особенно у детей. Мы представляем здесь редкий случай 12-летнего мальчика, жалующегося на нарастающую болезненную припухлость средней фаланги третьего пальца, которая началась 3 месяца назад и не отреагировала на воздействие противовоспалительных препаратов. На основании клинических данных и простых рентгенограмм подозревался остеомиелит или саркома Юинга. Однако ЯМР выявил типичные характеристики остеоидной остеомы. Поражение было вырезано, и гистологическое исследование подтвердило диагноз. Мы провели краткий обзор литературы по этой необычной локализации и обсудили дифференциальный диагноз и методы лечения. 